\title{
Prevalence of toxoplasma IgG among pregnant women in west London according to country of birth and ethnic group
}

\author{
R E Gilbert, P A Tookey, W D Cubitt, \\ A E Ades, J Masters, C S Peckham
}

Epidemiology and Biostatistics Unit, Institute of Child Health, London WC1N 1EH

R E Gilbert, lecturer in epidemiology

P A Tookey, research fellow A E Ades, senior lecturer in biostatistics

J Masters, research assistant C S Peckham, professor

Department of Virology, Hospitals for Sick Children, London WCiN 3JH

W D Cubitt, top grade virologist

Correspondence to: $\mathrm{Dr}$ Gilbert.

BMF 1993;306:185
Infection with Toxoplasma gondii can be acquired from soil contaminated by cats' faeces and by consumption of undercooked meat and unpasteurised goats' milk.' Toxoplasma cysts are killed by freezing or by heating above $45^{\circ} \mathrm{C}$. $^{\prime}$ Maternal infection can result in fetal infection and damage and is estimated to occur in $0 \cdot 1-0.5 \%$ of pregnancies in the United Kingdom. ${ }^{2}$ The seroprevalence of toxoplasma IgG is known to vary among countries, ${ }^{1}$ but differences according to country of birth and ethnic group have not previously been investigated in a single population based study.

\section{Patients, methods, and results}

Serum samples were collected from 6749 unselected women receiving antenatal care at two hospitals in west London during 1980-6. Maternal details recorded included country of birth and ethnic status. Women born in the Republic of Ireland or Northern Ireland were recorded as born in Ireland. British born Asian women were excluded, there being too few to analyse separately. Serum was analysed for toxoplasma $\mathrm{IgG}$ (Toxo-captia assay, Mercia Diagnostics, Guildford, Surrey). ${ }^{3}$ Titres $>12 \mathrm{IU} / \mathrm{ml}$ were regarded as positive results. Differences in the seroprevalence of toxoplasma IgG between groups stratified by age were tested by Mantel-Haenszel's $\chi^{2}$ method with one degree of freedom.

Prevalence of toxoplasma specific IgG by ethnic group and country of birth

\begin{tabular}{lcc}
\hline Ethnic group and place of birth & No tested & No (\%) seropositive \\
\hline Black Afro-Caribbean: & & \\
Britain & 278 & $34(12 \cdot 2)$ \\
Africa & 172 & $79(45 \cdot 9)$ \\
Caribbean & 320 & $106(33 \cdot 1)$ \\
Asian: & 317 & $24(7 \cdot 6)$ \\
India and Sri Lanka & 170 & $37(21 \cdot 8)$ \\
Pakistan and Bangladesh & 288 & $44(15 \cdot 3)$ \\
Africa & 172 & $16(9 \cdot 3)$ \\
Far East and South East Asia & 3768 & $502(13 \cdot 3)$ \\
White European: & 412 & $128(31 \cdot 1)$ \\
Britain & 70 & $50(71 \cdot 4)$ \\
Ireland & 34 & $3(8 \cdot 8)$ \\
France & 73 & $20(27 \cdot 4)$ \\
Scandinavia & 223 & $94(42 \cdot 2)$ \\
Rest of northern Europe & 337 & $91(27 \cdot 0)$ \\
Southern and eastern Europe & 115 & $39(33 \cdot 9)$ \\
Rest of world & & \\
Middle East & 6749 & $1267(18 \cdot 8)$ \\
\hline Total & & \\
\hline
\end{tabular}

Altogether, $1267(18 \cdot 8 \%)$ women were seropositive, of whom $731(57 \cdot 7 \%)$ had been born outside Britain (table). Seroprevalence differed significantly between women in the same ethnic group born in different countries-for example, between black women born in Britain (12.2\%) and those born in Africa (45.9\%) $\left(\chi^{2}=\right.$ $44.9, \mathrm{p}<0.001)$ and the Caribbean $(33.1 \%)\left(\chi^{2}=27.2\right.$, $\mathrm{p}<0.001$ ); between white women born in Ireland $(31 \cdot 1 \%)$ and those born in Britain (13.3\%) $\left(\chi^{2}=86.6\right.$, $\mathrm{p}<0.001)$; and between Asian women born in India and Sri Lanka $(7 \cdot 6 \%)$ and those born in Pakistan and Bangladesh $(21.8 \%)\left(\chi^{2}=18 \cdot 0, p<0.001\right)$.

Seroprevalence was similar in black and white British born women $(12 \cdot 2 \%$ and $13.3 \%$ respectively; $\left.\chi^{2}=1 \cdot 1, p>0 \cdot 25\right)$. In these women it increased with age from $9.0 \%(32 / 357)$ in women aged $<20$ to $26 \cdot 3 \%$ $(81 / 308)$ in women aged $\geqslant 35$.

\section{Comment}

The substantial differences in seroprevalence of toxoplasma IgG between women born in different countries suggest that women from countries with high prevalence of toxoplasmosis ${ }^{1}$ were infected before immigration to Britain. National dietary characteristics may partly explain the variations. For example, many of the predominantly Hindu women from India would have been vegetarian whereas Muslim women from Pakistan and Bangladesh would have eaten meat and may have been infected while preparing raw meat. In southern and eastern Europe uncooked meat, as dried or cured spiced sausage, is commonly eaten and may be a route of infection. Consumption of partially cooked meat and cheese made from unpasteurised goats' milk is common in France. The high seroprevalence of toxoplasma IgG among women born in Ireland compared with British born women may reflect differences in the consumption of undercooked meat or unpasteurised milk or in the use of freezers over the past 30-40 years. There are, however, no data to support such speculation.

Reduction in the seroprevalence of toxoplasma IgG has been observed in France, Austria, ${ }^{1}$ Sweden, ${ }^{4}$ and Britain. ${ }^{5}$ In Stockholm seroprevalence fell during 1969-87, coincident with increased consumption of frozen meat. ${ }^{4}$ In Britain consumption of meat has remained static over the past 20 years but ownership of freezers and the freezing of meat have increased dramatically. Previous British estimates of seroprevalence in women of childbearing age have ranged from $22 \%$ in England to $14-25 \%$ in Scotland. ${ }^{2}$ A report from south Yorkshire shows a decline in seroprevalence over the past 20 years with only $9.0 \%$ of women aged $16-40$ being seropositive in 1988-90. ${ }^{5}$

If antenatal screening was introduced to prevent congenital infection $87-91 \%$ of susceptible women born in Britain would require repeated serological testing throughout pregnancy. Differences in seroprevalence among countries point to the potential importance of eating habits. More detailed research is needed to determine the principal sources of infection in Britain, but health education may be an alternative to antenatal screening in reducing maternal infection.

Remington JS, Desmonts G. Toxoplasmosis. In: Remington JS, Klein JO, eds. Infectious diseases of the fetus and newborn infant. 3rd ed. Philadelphia: W B Saunders, 1990:90-195.

2 Ades AE. Methods for estimating the incidence of primary infection in pregnancy: a reappraisal of toxoplasmosis and cytomegalovirus data. Epidemiol Infect 1992;108:367-75.

3 Cubitt WD, Ades AE, Peckham CS. An evaluation of five commercial assays fo screening antenatal sera for the presence of antibodies to Toxoplasma gondii. fClin Pathol 1992;45:435-8.

4 Forsgren M, Gille E, Ljungstrom I, Nokes DJ. Toxoplasma gondii antibodies in pregnant women in Stockholm in 1969, 1979 and 1987. Lancet 1991;337: $1413-4$

5 Walker J, Nokes DJ, Jennings R. Longitudinal study of toxoplasma seroprevalence in south Yorkshire. Epidemiol Infect 1992;108:99-106.

(Accepted 30 September 1992) 